National Marine

Fisheries Service

NOAA
Fishery Bulletin

as established in 1881 ๙
Spencer F. Baird

First U.S. Commissioner of Fisheries and founder of Fishery Bulletin
Abstract-The landings of the artisanal elasmobranch fisheries of $3 \mathrm{com}$ munities located along the Pacific coast of Guatemala from May 2017 through March 2020 were evaluated. Twentyone elasmobranch species were identified in this study. Bottom longlines used for multispecific fishing captured ray species and represented $59 \%$ of the fishing effort. Gill nets captured small shark species and represented $41 \%$ of the fishing effort. The most frequently caught species were the longtail stingray (Hypanus longus), scalloped hammerhead (Sphyrna lewini), and Pacific sharpnose shark (Rhizoprionodon longurio), accounting for $47.88 \%$, $33.26 \%$, and $7.97 \%$ of landings during the monitoring period, respectively. The landings were mainly neonates and juveniles. Our findings indicate the presence of nursery areas on the continental shelf off Guatemala. This study included the first survey of commercial exploitation of ray species in the artisanal fisheries off the Pacific coast of Guatemala. It is imperative to protect shark nursery areas and to develop management strategies for ray species that are important to artisanal fisheries.

Manuscript submitted 9 July 2020. Manuscript accepted 19 January 2021. Fish. Bull. 119:3-9 (2021).

Online publication date: 2 March 2021. doi: 10.7755/FB.119.1.2

The views and opinions expressed or implied in this article are those of the author (or authors) and do not necessarily reflect the position of the National Marine Fisheries Service, NOAA.

\title{
Characterization of the artisanal elasmobranch fisheries off the Pacific coast of Guatemala
}

\author{
Cristopher G. Avalos Castillo (contact author) ${ }^{1,2}$ \\ Omar Santana Morales ${ }^{3,4}$
}

Email address for contact author: criss.ac.13@gmail.com

${ }^{1}$ Fundación Mundo Azul

Carretera a Villa Canales

km 21-22 Finca Moran

01069 Villa Canales, Guatemala

${ }^{2}$ Centro de Estudios del Mar y Acuicultura Universidad de San Carlos de Guatemala Ciudad Universitaria Zona 12

Edificio M14

01012 Guatemala City, Guatemala
${ }^{3}$ Facultad de Ciencias Marinas Universidad Autónoma de Baja California Carretera Ensenada-Tijuana 3917 Fraccionamiento Playitas 22860 Ensenada, Baja California, Mexico

${ }^{4}$ ECOCIMATI A.C. Avenida del Puerto 2270 Colonia Hidalgo 22880 Ensenada, Baja California, Mexico
Despite the widespread consumption and commercialization of elasmobranch catches in Latin America, there are no consistent statistical records and few studies of the catches of elasmobranch species in Guatemala or of products made from captured individuals. Nonetheless, Hacohen-Domené et al. (2020) described an artisanal elasmobranch fishery on the Caribbean coast of Guatemala and evaluated biological data from 688 Chondrichthyan species ( 24 shark, 6 ray, and 1 chimaera species) landed from January 2015 through July 2017. They concluded that a high proportion of the specimens of shark species for which data were recorded were juveniles. Ruíz Alvarado and Mijangos López (1999) first described the shark fisheries that operate off the Pacific coast of Guatemala and recorded 15 landed species. The most recent study about sharks species, which included a monitoring program of 5 communities along the Pacific coast, was carried out during 2006-2007 by Ixquiac Cabrera et al. ${ }^{1}$, who found that the

\footnotetext{
${ }^{1}$ Ixquiac Cabrera, J., I. Franco Arenales, C. A. Tejeda Velásquez, M. R. Sánchez Rodas, and J. A. Sikahall Prado. 2009. Áreas de crianza
}

most captured species were the silky shark (Carcharhinus falciformis), scalloped hammerhead (Sphyrna lewini), and whitenose shark (Nasolamia velox). Lastly, in the most recent study about ray species in 2006, Ixquiac Cabrera et al. $^{2}$ determined that the main species of Guatemala's continental shelf are the golden cownose ray (Rhinoptera steindachneri), longtail stingray (Hypanus longus), and blotched stingray (Urotrygon chilensis).

The aim of this study was to continuously monitor the landings of artisanal fisheries of 3 Pacific coast communities in Guatemala from May 2017 through

de tiburones en la plataforma continental del Pacífico de Guatemala: Herramienta para el manejo y aprovechamiento sostenido del recurso tiburón. Proyecto Fodecyt 13-2006, 48 p. Cent. Estud. Mar Acuic., Univ. San Carlos Guatemala, Guatemala City, Guatemala. [In Spanish.] [Available from website.]

2 Ixquiac Cabrera, M., I. Franco, J. Lemus, S. Méndez, and A. López-Roulet. 2010. Identificación, abundancia, distribución espacial de batoideos (rayas) en el Pacífico guatemalteco. Proyecto Fodecyt 34-2006, 41 p. Fondo Nac. Cienc. Tecnol., Cent. Estud. Mar Acuic., Organ. Conserv. el Medio Ambiente, Guatemala. [In Spanish.] [Available from website.] 
March 2020 and ultimately to provide the first characterization of the ray species captured by the artisanal fleet and the shark species present in landings. The information from this study will contribute to the identification of elasmobranch nursery areas in Guatemala and facilitate the design of conservation strategies. Our results highlight the need to establish rays as important fishery species in this region.

\section{Materials and methods}

\section{Study area}

Approximately 1.8 million people live in the communities along the Pacific coast of Guatemala ( $14 \%$ of the national population), and the main sources of income for these people are related to fishing activities (SEGEPLAN and $\mathrm{DOT}^{3}$ ). The continental platform of Guatemala $\left(14,009 \mathrm{~km}^{2}\right)$ is narrow, extends $\sim 50 \mathrm{~km}$ offshore, and contains the economic exclusive zone of the country. Along the $250-\mathrm{km}$ coastline where Guatemala meets the Pacific Ocean, about 45 communities have artisanal fisheries, in which elasmobranch species are incidentally captured and landed. Three of the largest fishing communities were selected for this study: Las Lisas, Buena Vista, and Sipacate (Fig. 1). These communities were selected for their importance and because their fishing efforts were greater than those of the other communities in the region. The community of Buena Vista was not monitored in the study until January 2019.

\section{Landings}

Biological and morphometric data were collected from elasmobranchs sampled from landings between May 2017 and March 2020, in addition to information on fishing effort and gear. Over the study period, sampling was undertaken during 83 visits to the 3 fishing communities: 34 visits in Las Lisas, 35 visits in Sipacate, and 14 visits in Buena Vista. Most individuals were landed whole and were identified to the species level by using identification guides and specialized books (Mejía-Falla et al., 2011; Ebert et al., 2013; Last et al., 2016). The sources for the nomenclature of ray, shark, and shrimp species were Last et al. (2016), Ebert et al. (2013), and Holthuis (1980), respectively. The presence or absence of

\footnotetext{
${ }^{3}$ SEGEPLAN (Secretaría de Planificación y Programación de la Presidencia) and DOT (Dirección de Ordenamiento Territorial). 2011. Plan de desarrollo integral del litoral del Pacífico, 190 p. SEGEPLAN and DOT, Guatemala City, Guatemala. [In Spanish.] [Available from website.]
}

male claspers was used to determine the sex of each specimen. Maturity was determined by the degree of clasper calcification (males) and the presence of reproductive scars or embryos (females). Size at first maturity was obtained from the literature (Mejía-Salazar, 2007; Navia et al., 2009; Zanella et al., 2009; López-Garro and Zanella, 2015; Pollom et al., 2020). Measurements to the nearest $0.5 \mathrm{~cm}$ were recorded for landed individuals in a natural position. For sharks, total length was measured by using the natural extension of the caudal fin (Compagno, 2001), and fork length was recorded. For rays, disc width and disc length were recorded. Total length was also recorded for small rays.

Given that the vessels in the artisanal fisheries used a variable and unquantifiable quantity of fishhooks or nets, the landings per unit of effort (LPUE) was calculated for each species by using fishing nights as the unit of effort. To ensure that calculations were as accurate as possible, an attempt was made to count the total number of elasmobranchs per fishing trip (every shark and ray landed by every boat that arrived at the dock on monitoring days), even if it was not possible to measure all individuals. For species in which the number of sampled individuals $(n)$ was greater than 15, size histograms were generated and compared with information on sexual maturity from the literature.

In Las Lisas, a trawl fishery directed at the whiteleg shrimp (Litopenaeus vannamei) and seabob (Xiphopenaeus kroyeri) is also present. Data on incidentally caught 
elasmobranchs were collected from the landings of the trawl boats in this fishery. Data recorded includes size, sex, and maturity. For this fishery, it was not possible to calculate LPUE.

\section{Results and discussion}

\section{Fishing activity}

The fishing activities of the communities in this study are carried out year-round, and there are no restrictions or seasonal closures. Fishermen do not engage in other economic activities. The fishermen from Las Lisas worked independently from one another, owned their own boats, and went fishing 5-6 d per week; the durations of their fishing trips were 1-2 nights. The fishermen from Sipacate and Buena Vista were hired by boat owners to work as part of fishing fleets (1-10 boats), and the durations of their fishing trips were generally 2 nights. Two types of fishing gears were identified: bottom and mid-water gill nets made of monofilament (mesh: 4-6 cm; length: 300-700 m; height: 5-7 m) and bottom longlines with small $J$ hooks or Eagle $\mathrm{Claw}^{4}$ half circle hooks (Wright and McGill Co., Denver, CO; height: $3-6 \mathrm{~cm}$ ). The gill nets were linked together (maximum of 5 connected nets), remained in the water for 5-6 h, and were used 3-5 times per trip. Although gill nets were set to catch bony fish species, small sharks and rays were incidentally caught as species of moderate-to-high commercial value. The bottom longlines spanned $2-6 \mathrm{~km}$, contained 300-700 hooks, remained in the water for 3-4 h, and were changed 2-4 times per trip. The bottom longlines targeted demersal bony fish and ray species, and some shark species were incidentally caught.

The artisanal fisheries of the communities of Las Lisas, Sipacate, and Buena Vista are classified as commercial demersal and small pelagic fisheries, according to the General Law of Fisheries and Aquaculture of Guatemala (MAGA, 2002), and do not include the capture of elasmobranch species as target species. A notable problem is that artisanal fishing activities are carried out without permits from the Fisheries and Aquaculture Regulations Department of Guatemala because of a lack of resources.

\section{Landings}

In Las Lisas, 131 fishing trips were recorded, of which 70 trips (53\%) used gill nets and 61 trips (47\%) used bottom longlines. In addition, landings of 3 shrimp trawl boats with incidentally caught elasmobranchs were evaluated. Data on 669 elasmobranchs were recorded. In total, $48 \%$ $(n=321)$ and $41 \%(n=274)$ of the sampled individuals were caught in gill nets and bottom longlines, respectively. Finally, shrimp trawl nets were responsible for only $11 \%$ $(n=74)$ of the incidentally caught individuals. In this

\footnotetext{
${ }^{4}$ Mention of trade names or commercial companies is for identification purposes only and does not imply endorsement by the National Marine Fisheries Service, NOAA.
}

location, 6 species were identified ( 3 shark and 3 ray species; Table 1). Only 6\% ( $n=37)$ of the recorded individuals were mature (Fig. 2).

In Sipacate, fishing vessels use longlines and gill nets simultaneously. During 282 fishing trips (64\%), 103 fishing trips (23\%), and 57 fishing trips (13\%), elasmobranch species were caught with both gears, longlines only, and gill nets only, respectively. In total, 2603 elasmobranchs were recorded, of which 1608 individuals (62\%) were captured with bottom longlines and 991 individuals (38\%) were captured with gill nets. A total of 16 species were identified (9 shark and 7 ray species; Table 1). Only 7\% $(n=179)$ of the specimens were mature (Fig. 2).

In Buena Vista, fishing vessels used longlines and gill nets simultaneously. In 50 fishing trips (57\%), 21 fishing trips (24\%), and 17 fishing trips (19\%), both gears, bottom longlines only, and gill nets only were used, respectively. Information was obtained on 526 elasmobranchs, of which 271 individuals $(52 \%)$ were captured with bottom longlines and 255 individuals (48\%) were captured with gill nets. A total of 17 species were identified in this location (8 shark and 9 ray species; Table 1). Only $4 \%(n=24)$ of the specimens were mature (Fig. 2). The statistics for rarely landed species $(n<15)$ in all 3 communities are presented in Table 2.

The LPUE varied over the course of the study, and periods of high LPUE values were determined for each species. The shark species that appeared most in the landings was the scalloped hammerhead (70\% of landings), and the longtail stingray was the most common ray (91\% of landings). For the longtail stingray, most of the landings occurred during the first months of the year. An increase in landings during the rainy season was observed for the scalloped hammerhead (May-September).

The scalloped hammerhead was 1 of 5 shark species that dominated the landings in Guatemala during 1997-1999 (Ruíz Alvarado et al. ${ }^{5}$ ), and during 2006-2007, the scalloped hammerhead was the second-most-caught shark species along the Pacific coast of Guatemala. Abundance of scalloped hammerhead has also been observed to be higher during the rainy season in Costa Rica (Zanella et al., 2009) and Mexico (Alejo-Plata et al., 2007) than during other seasons; during the rainy season, waters in coastal areas have higher concentrations of nutrients than during other periods. The fishing areas of the communities of Las Lisas and Sipacate evaluated in our study correspond to 2 of the 3 nursery areas used by scalloped hammerhead that were identified by Ixquiac Cabrera et al. ${ }^{1}$, areas in which $88 \%$ of the landed individuals were classified as either neonates or juveniles. Ten years later, the results of our study indicate a continued presence of neonates and juveniles in these areas. According to this information and to the 3 criteria

\footnotetext{
${ }^{5}$ Ruíz Alvarado, C., M. Ixquiac Cabrera, C. Baldetti Herrera, and J. Martínez. 2000. Evaluación del potencial de explotación del recurso tiburón en las costas del Pacífico de Guatemala, 56 p. Fondo Nac. Cienc. Tecnol., Cent. Estud. Mar Acuic., Unidad Manejo Pesca Acuic., Guatemala. [In Spanish.] [Available from website.]
} 


\section{Table 1}

Statistics for elasmobranch species landed from May 2017 through March 2020 in artisanal fisheries that operate from 3 communities off the Pacific coast of Guatemala: Las Lisas, Sipacate, and Buena Vista. The number of documented individuals $(n)$, percentage of the landing records, landings per unit of effort (LPUE) with fishing nights used as unit of effort, and fishing gear used to capture individuals are provided for each species by community. The LPUE is not presented for vermiculate electric rays (Narcine vermiculata) landed in Las Lisas because they were captured by shrimp trawl boats.

\begin{tabular}{|c|c|c|c|c|c|c|c|c|c|c|}
\hline \multirow[b]{2}{*}{ Species } & \multicolumn{3}{|c|}{ Las Lisas } & \multicolumn{3}{|c|}{ Sipacate } & \multicolumn{3}{|c|}{ Buena Vista } & \multirow[b]{2}{*}{ Fishing gear } \\
\hline & $n$ & $\%$ & LPUE & $n$ & $\%$ & LPUE & $n$ & $\%$ & LPUE & \\
\hline Hypanus longus & 258 & 39 & 1.73 & 1328 & 51 & 1.60 & 239 & 44 & 1.39 & Bottom longline \\
\hline Sphyrna lewini & 348 & 52 & 2.33 & 716 & 28 & 0.86 & 204 & 38 & 1.18 & Gill net \\
\hline Rhizoprionodon longurio & & & & 289 & 11 & 0.35 & 15 & 3 & 0.08 & Gill net \\
\hline Mustelus lunulatus & & & & 170 & 7 & 0.20 & 5 & 1 & 0.02 & Bottom longline \\
\hline Carcharhinus limbatus & 1 & $<1$ & 0.01 & 32 & 1 & 0.03 & 2 & $<1$ & 0.01 & Gill net \\
\hline Narcine vermiculata & 57 & 9 & - & 30 & 1 & 0.03 & 4 & 1 & 0.02 & Gill net \\
\hline Aetobatus laticeps & 4 & 1 & 0.02 & 8 & $<1$ & 0.01 & 7 & 1 & 0.04 & Bottom longline \\
\hline Pseudobatos leucorhynchus & & & & 7 & $<1$ & 0.01 & 17 & 3 & 0.09 & Gill net \\
\hline Galeocerdo cuvier & 1 & $<1$ & 0.01 & 7 & $<1$ & 0.01 & & & & Gill net \\
\hline Narcine entemedor & & & & 4 & $<1$ & 0.01 & & & & Bottom longline \\
\hline Styracura pacifica & & & & 3 & $<1$ & 0.01 & & & & Bottom longline \\
\hline Nasolamia velox & & & & 2 & $<1$ & $<0.01$ & 1 & $<1$ & 0.01 & Gill net \\
\hline Carcharhinus falciformis & & & & 2 & $<1$ & $<0.01$ & 11 & 2 & 0.06 & Gill net \\
\hline Rhinoptera steindachneri & & & & 2 & $<1$ & $<0.01$ & 2 & $<1$ & 0.01 & Bottom longline \\
\hline Carcharhinus leucas & & & & 2 & $<1$ & $<0.01$ & 1 & $<1$ & 0.01 & Bottom longline \\
\hline Sphyrna mokarran & & & & 1 & $<1$ & $<0.01$ & & & & Bottom longline \\
\hline Mobula thurstoni & & & & & & & 25 & 5 & 0.14 & Gill net \\
\hline Mobula munkiana & & & & & & & 3 & 1 & 0.01 & Gill net \\
\hline Urotrygon aspidura & & & & & & & 2 & $<1$ & 0.01 & Gill net \\
\hline Urotrygon chilensis & & & & & & & 1 & $<1$ & 0.01 & Gill net \\
\hline Alopias pelagicus & & & & & & & 1 & $<1$ & 0.01 & Bottom longline \\
\hline Total & 669 & 100 & & 2603 & 100 & & 540 & 100 & & \\
\hline
\end{tabular}

that were established by Heupel et al. (2007) for the definition of a shark nursery area, it is highly probable that these sites are important nursery areas for the scalloped hammerhead in the eastern central Pacific Ocean.

The 3 criteria of Heupel et al. (2007) used to define a nursery area for shark species are as follows: 1) sharks of a species are most commonly found in a particular area instead of in other areas (for example, the density in some areas is higher than in other areas), 2) neonate and youngof-the-year sharks tend to remain or return for extended periods of time (weeks or months) in an area, and 3) an area or habitat is used repeatedly over the years while other sites are not.

Other shark species also had high incidences of capture during specific times of the year. For example, $75 \%$ of the landings of the Pacific sharpnose shark (Rhizoprionodon longurio) occurred during November 2018, and blacktip sharks (C. limbatus) were caught only from February through May in 2018 and 2019. Seasonality has also been observed for landings of the Pacific sharpnose shark off the Pacific coast of Mexico, with a high proportion of the total catch occurring from November through April (MárquezFarias, 2005). Interestingly, the Pacific sharpnose shark has not been reported in previous studies of fisheries in
Guatemala despite being a common species in the eastern central Pacific Ocean (Márquez-Farias, 2005). Although Ixquiac Cabrera et al. ${ }^{1}$ reported that the silky shark was the most abundant shark species in landings recorded in Guatemala during 2006-2007, only a few individuals were observed in our study. The difference in abundance for this species may be a result of the inclusion of offshore longline fisheries in previous studies and the focus of our study on only coastal fisheries.

The results of our study provide the first characterization of ray exploitation in the artisanal fisheries of Guatemala. In total, 11 ray species were identified, with the longtail stingray having the most records $(n=1825)$. It is important to mention that not all ray species are locally exploited, as is the longtail stingray, given that some do not reach large sizes. According to the information obtained in this study, the meat of longtail stingrays was mainly used locally in fillet form. As such, it has become a target species for the multispecies bottom longline fishery in Sipacate and to lesser extents for the fisheries in Las Lisas and Buena Vista. The remaining ray species that reached large sizes and that were occasionally reported were the Pacific eagle ray (Aetobatus laticeps), Pacific chupare (Styracura pacifica), and golden cownose ray, all of which are consumed 


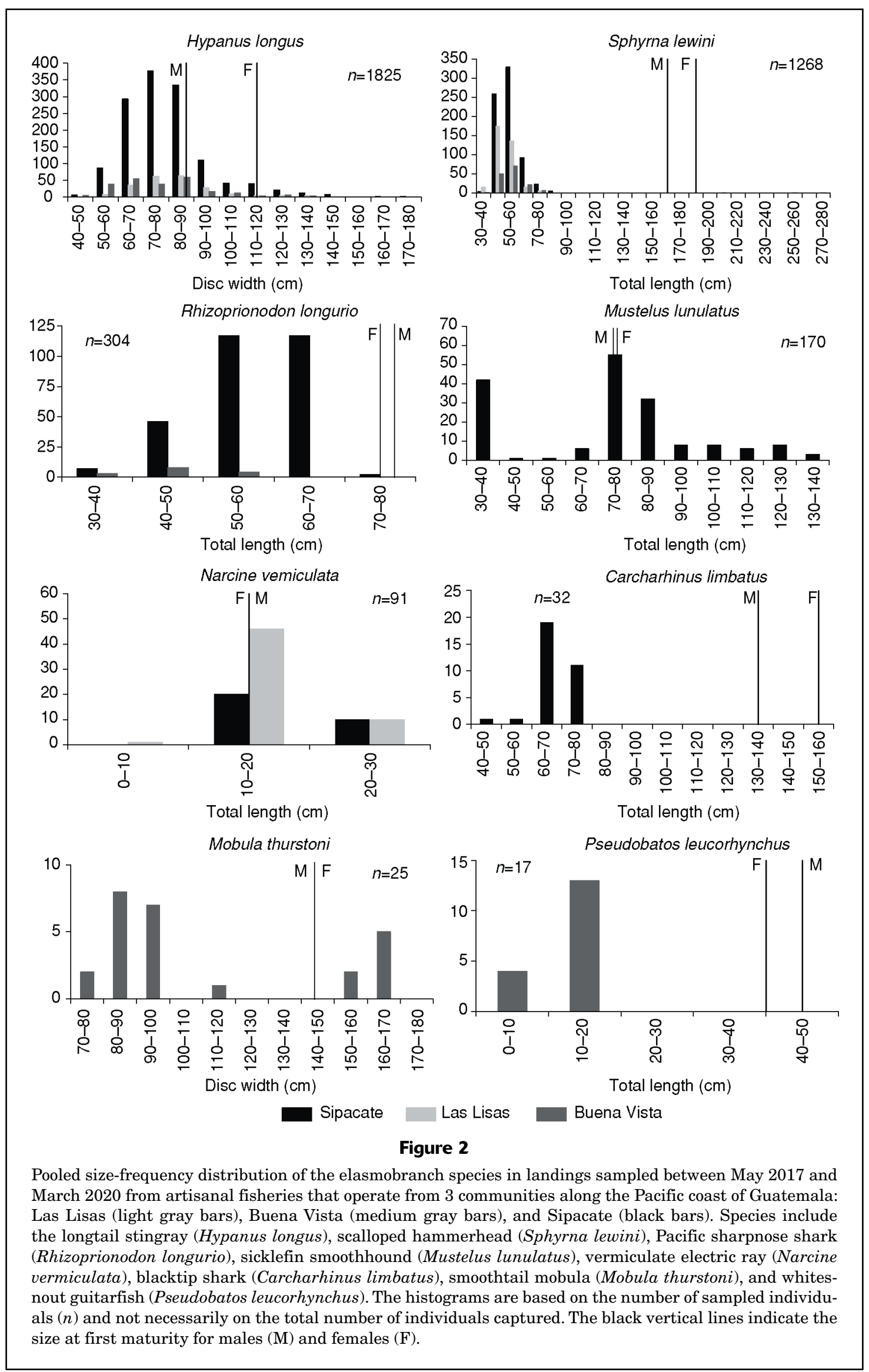




\section{Table 2}

Statistics for elasmobranch species rarely landed from May 2017 through March 2020 in artisanal fisheries that operate from 3 communities along the Pacific coast of Guatemala: Las Lisas, Sipacate, and Buena Vista. The number of documented individuals $(n)$, mean size (total length or disc width, depending on the species), and standard error of the mean (SE) are presented for each species by community. The interdorsal lengths of pelagic threshers (Alopias pelagicus) were recorded because they were landed without heads or caudal fins. Species are considered rarely landed if $n<15$.

\begin{tabular}{|c|c|c|c|c|c|c|c|c|c|}
\hline \multirow[b]{2}{*}{ Species } & \multicolumn{3}{|c|}{ Las Lisas } & \multicolumn{3}{|c|}{ Sipacate } & \multicolumn{3}{|c|}{ Buena vista } \\
\hline & $n$ & $\begin{array}{c}\text { Mean } \\
\text { size }(\mathrm{cm})\end{array}$ & $\mathrm{SE}$ & $n$ & $\begin{array}{c}\text { Mean } \\
\text { size }(\mathrm{cm})\end{array}$ & $\mathrm{SE}$ & $n$ & $\begin{array}{c}\text { Mean } \\
\text { size }(\mathrm{cm})\end{array}$ & $\mathrm{SE}$ \\
\hline Aetobatus laticeps & 4 & 79.75 & 5.09 & 8 & 81.81 & 2.45 & 7 & 87.21 & 10.36 \\
\hline Carcharhinus falciformis & & & & 2 & 92.00 & 1.00 & 11 & 86.45 & 3.53 \\
\hline Galeocerdo cuvier & 1 & 90.50 & - & 7 & 89.29 & 0.71 & & & \\
\hline Pseudobatos leucorhynchus & & & & 7 & 32.71 & 4.43 & & & \\
\hline Mustelus lunulatus & & & & & & & 5 & 60.01 & 5.33 \\
\hline Narcine entemedor & & & & 4 & 49.25 & 10.94 & & & \\
\hline Rhinoptera steindachneri & & & & 2 & 74.50 & 9.50 & 2 & 77.50 & 0.50 \\
\hline Narcine vermiculata & & & & & & & 4 & 20.75 & 1.03 \\
\hline Nasolamia velox & & & & 2 & 59.50 & 1.50 & 1 & 68.00 & - \\
\hline Mobula munkiana & & & & & & & 3 & 101.33 & 0.33 \\
\hline Styracura pacifica & & & & 3 & 77.33 & 5.90 & & & \\
\hline Carcharhinus leucas & & & & 2 & 109.00 & 11.00 & 1 & 262.00 & - \\
\hline Carcharhinus limbatus & & & & & & & & & \\
\hline Urotrygon aspidura & & & & & & & 2 & 10.75 & 0.25 \\
\hline Sphyrna mokarran & & & & 1 & 122.00 & - & & & \\
\hline Alopias pelagicus & & & & & & & 1 & 16.00 & \\
\hline Urotrygon chilensis & & & & & & & 1 & 10.50 & - \\
\hline
\end{tabular}

locally. Fishermen indicated that the vermiculate electric ray (Narcine vermiculata) is used as bait in the bottom longline fisheries. Dulvy et al. (2000) highlighted that batoid species in general are arguably the most vulnerable species in marine fisheries. Clarke et al. (2018) conducted a productivity susceptibility analysis for elasmobranch species in bottom fisheries and revealed that the longtail stingray is one of the most vulnerable species in Costa Rica, mainly because of its low reproductive potential and distribution, which overlaps greatly with shallow-water fishing grounds.

\section{Conservation and management}

Although elasmobranch species are not recognized as target species in artisanal fisheries in Guatemala, they are captured in high volumes during several months of the year and, therefore, account for a high percentage of the income of fishermen. There are currently no regulations for the management and conservation of elasmobranch species off the Pacific coast of Guatemala, and most artisanal fleets operate without permits or official records. Although all shark species can be exploited in artisanal, large-scale, or industrial fisheries (MAGA, 2002), ray species are not included as target species for any coastal fishery. Currently, the nongovernmental organization Fundación Mundo Azul and the Fisheries and Aquaculture Regulations Department of Guatemala have created a technical group to supervise and update the management plan for the conservation of Chondrichthyan species in Guatemala (this plan is in the final stages of approval and publication). However, Guatemala has not yet imposed national fishing regulations for any elasmobranch species, as other countries in Latin America, such as Mexico, have done (Saldaña-Ruiz et al., 2019). Off the Pacific coast of Mexico, shark nursery areas have been considered priority areas for elasmobranch conservation, and legislation has banned fishing activities inside those areas (Saldaña-Ruiz et al., 2019).

In Guatemala, it is also necessary to protect elasmobranch nursery areas, particularly for the scalloped hammerhead, which is listed as critically endangered in the IUCN Red List of Threatened Species and uses areas along the coasts of Guatemala during the early stages of its life cycle (Rigby et al., 2019). In addition, it is important to develop adequate management strategies because rays are highly vulnerable to coastal fisheries because of their very low productivity potential (Clarke et al., 2018). Therefore, it is important to support conservation actions and continuous monitoring efforts to improve the management of elasmobranch species in the eastern central Pacific Ocean. 


\section{Acknowledgments}

This study was supported by the Fundación Mundo Azul, the Rufford Foundation (grant no. 22366-1), the PADI Foundation (grant no. 32809), the Waitt Foundation (grant no. 44306), and the Shark Conservation Fund. We thank the National Council of Protected Areas of Guatemala for issuing the research license (license no. I-DRSO-001-2018) and J. Ortíz and the Center for Marine Studies and Aquaculture of the University of San Carlos of Guatemala for their support. We recognize A. Hacohen Domené for her support of the master thesis of the senior author. We are especially grateful for the support in the field provided by F. Polanco, A. Paz, and the fishermen we worked with and for the contributions of D. Cartamil.

\section{Literature cited}

Alejo-Plata, C., J. L. Gómez-Márquez, S. Ramos, and E. Herrera. 2007. Presencia de neonatos y juveniles del tiburón martillo Sphyrna lewini (Griffith and Smithe, 1834) y del tiburón sedoso Carcharhinus falciformis (Müller and Henle, 1839) en la costa de Oaxaca, México. Rev. Biol. Mar. Oceanogr. 42:403-413. [In Spanish.] Crossref

Pollom, R., J. Bizzarro, M. I. Burgos-Vázquez, C. Avalos, M. Espinoza,

A. González, J. C. Pérez Jiménez, and O. Sosa-Nishizaki.

2020. Narcine vermiculatus. The IUCN Red List of Threatened Species 2009:e.T161423A124482181. [Available from website, accessed June 2020.]

Clarke, T. M., M. Espinoza, R. R. Chaves, and I. S. Wehrtmann.

2018. Assessing the vulnerability of demersal elasmobranchs to a data-poor shrimp trawl fishery in Costa Rica, Eastern Tropical Pacific. Biol. Conserv. 217:321-328. Crossref

Compagno, L. V. J.

2001. Sharks of the world. An annotated and illustrated catalogue of shark species known to date. Vol. 2. Bullhead, mackerel and carpet sharks (Heterodontiformes, Lamniformes and Orectolobiformes). FAO species catalogue for fishery purposes 1, 269 p. FAO, Rome.

Dulvy, N. K., J. D. Metcalfe, J. Glanville, M. G. Pawsan, and J. D. Reynolds.

2000. Fishery stability, local extinctions, and shifts in community structure in skates. Conserv. Biol. 14:283-293. Crossref

Ebert, D. A., S. Fowler, and L. Compagno.

2013. Sharks of the world: a fully illustrated guide, 528 p. Wild Nat. Press, Plymouth, UK.

Hacohen-Domené, A., F. Polanco-Vásquez, C. Estupiñan-Montaño, and R. T. Graham.

2020. Description and characterization of the artisanal elasmobranch fishery on Guatemala's Caribbean coast. PloS ONE 15(1):e0227797. Crossref

Heupel, M. R., J. K. Carlson, and C. A. Simpfendorfer.

2007. Shark nursery areas: concepts, definition, characterization and assumptions. Mar. Ecol. Prog. Ser. 337:287-297. Crossref

Holthuis, L. B.

1980. FAO species catalogue. Vol. 1. Shrimps and prawns of the world. An annotated catalogue of species of interest to fisheries. FAO Fish. Synop. 125, 271 p. FAO, Rome.
Last, P. R., W. T. White, M. R. de Carvalho, B. Séret, M. F. W. Stehmann, and G. J. P. Naylor (eds.).

2016. Rays of the world, 832 p. Cornell Univ. Press, Ithaca, NY. López-Garro, A., and I. Zanella.

2015. Capturas de la raya Dasyatis longa (Myliobatiformes: Dasyatidae) en las pesquerías artesanales de Golfo Dulce, Costa Rica. Rev. Biol. Trop. 63(Suppl. 1):319-327. [In Spanish.] Crossref

MAGA (Ministerio de Agricultura, Ganadería y Alimentación). 2002. Ley general de pesca y acuitultura. Decreto no. 80-2002. Congreso de la Republica de Guatemala, Guatemala City, Guatemala. [In Spanish.] [Available from website.]

Márquez-Farias, J. F.

2005. Gillnet mesh selectivity for the shovelnose guitarfish (Rhinobatos productus) from fishery-dependent data in the artisanal ray fishery of the Gulf of California, Mexico. J. Northwest Atl. Fish. Sci. 35:443-452. Crossref

Mejía-Falla, P. A., A. F. Navia, and V. Puentes (eds.).

2011. Guía para la identificación de especies de tiburones, rayas y quimeras de Colombia, 338 p. Ministerio de Ambiente y Desarrollo Sostenible; Corporación para el Desarrollo Sostenible del Archipiélago de San Andrés, Providencia y Santa Catalina-CORALINA; Gobernación de San Andrés, Providencia y Santa Catalina; Fundación SQUALUS. Bogotá, Colombia. [In Spanish.] [Available from website.]

Mejía-Salazar, L.

2007. Biología reproductiva del cazón bironche, Rhizoprionodon longurio (Jordan and Gilbert, 1882) en el Pacífico Mexicano. M.S. thesis, 67 p. Cent. Interdiscip. Cienc. Mar., Inst. Politéc. Nac., La Paz, Mexico. [Available from website.]

Navia, A. F., P. A. Mejía-Falla, L. A. Zapata, S. Bessudo, G. Soler, and E. A. Rubio.

2009. Estado del conocimiento de tiburones y rayas del Pacífico colombiano. In Avances en el conocimiento de tiburones, rayas y quimeras de Colombia (V. Puentes, A. F. Navia, P. A. Mejía-Falla, J. P. Caldas, M. C. Diazgranados, and L. A. Zapáta, eds.), p. 133-194. Fundación SQUALUS, Ministerio de Ambiente, Vivienda y Desarrollo Territorial, Instituto Colombiano Agropecuario, COLCIENCIAS, Conservación Internacional, WWF, Colombia.

Rigby, C. L., N. K. Dulvy, R. Barreto, J. Carlson, D. Fernando, S. Fordham, M. P. Francis, K. Herman, R. W. Jabado, K. M. Liu et al.

2019. Sphyrna lewini. The IUCN Red List of Threatened Species. 2019:e.T39385A2918526. [Available from website, accessed May 2020.]

Ruíz Alvarado, C. L., and N. Mijangos López.

1999. Estudio sobre la pesquería del tiburón en Guatemala. In Case studies of the management of elasmobranch fisheries (R. Shotton, ed.), p. 174-198. FAO Fish. Tech. Pap. 378, part 1. FAO, Rome. [In Spanish.] [Available from website.]

Saldaña-Ruiz, L. E., E. García-Rodríguez, J. C. Pérez-Jiménez, J. Tovar-Ávila, and E. Rivera-Téllez.

2019. Chapter 2-biodiversity and conservation of sharks in Pacific Mexico. Adv. Mar. Sci. 83:11-60. Crossref

Zanella, I., A. López, and R. Arauz.

2009. Characterization of the fishing of the hammer shark, Sphyrna lewini, in the external part of the Gulf of Nicoya, Costa Rica. J. Mar. Coast. Sci. 1:175-195. [In Spanish.] Crossref 